Јелица Д. Јокановић-Михајлов

Универзитет у Београду

Филолошки факултет

Катедра за српски језик

са јужнословенским језицима

https://doi.org/10.18485/ai_fonefonosj.2020.ch2

811.163.41'342.8

\title{
ПРОЗОДИЈСКЕ ИНОВАЦИЈЕ И СТАБИЛНОСТ АКЦЕНАТСКЕ ПАРАДИГМЕ
}

У раду се анализира фонетска база акценатских промена које доводе до мењања постојећих акценатских парадигми, издвајају се компоненте које мењају акценат речи или њену ритмичку структуру и процењује функционална вредност нових облика. Актуелне прозодијске иновације се пореде са одговарајућим иновацијама из ранијег периода и утврђује се обим и карактер садашњих промена.

Кључне речи: акценатска парадигма, иновације, ортоепија, говорна култура

Констатација да се у нашем прозодијском систему срећу облици који одударају од оних који се сматрају правилнима и које препоручују језичка литература и приручници, као и то да их је у пракси збиља много, неће никога изненадити. Велики је број оваквих облика и свако их је чуо, а најчешће се и сам више пута колебао да ли неке од њих употребити или заменити онима које је норма прихвила као једине исправне.

\footnotetext{
* j.j.mihajlov@fil.bg.ac.rs
} 
Они упућенији у језичку проблематику обично покушавају да процене колика је стварна потреба да такав свој облик замене препорученим, а они који су непосредно у овој материји, акцентолози, често се муче изналажењем објашњења за прихватање или неприхватање одређених облика. Сви смо, дакле, свесни да се прозодијска норма мора поштовати, али и да се мора у понечему мењати, да је то природни језички процес. Колико и када је мењати, питање је на које се могу чути најразличитији одговори, посебно од говорника који се језиком не баве професионално и који су обично увек за промене, радикалне и брзе, док ће код језичких стручњака, свесних тешкоћа и одговорности које прате увођење промена, а истовремено свесних и сложености издвајања и утврђивања критеријума према којима би се промене морале уводити, одговор често бити неодређен и помало замагљен, а неретко га неће ни исказати. Њихово сазнање да је норма у основи конзервативна и да то није њена мана него врлина, јер она тако чува систем од превременог и случајног, несистемског мењања, наводиће их често да не прихватају ни облике који у говору великог броја образованих људи, са добром општом и језичком културом, почињу да конкуришу, па и да преовлађују над облицима које је норма одраније утврдила као исправне. Тако ригидни ставови обично не доприносе очувању прозодијске норме, већ о њој код говорника стварају негативну слику, а стварају код њих и негативан однос према реалној потреби да сопствени говор доводе у склад са правилима књижевног изговора. С друге стране, поменути ригидни став одбијања промена, у својој основи је пасиван: он не настоји да образложи зашто би нека иновација била лоша, он само неће да се било шта мења. Јасно је да иновације могу бити и добре и лоше, као и да ће се само неке касније показати као по- 
зитивне и корисне у прозодијском систему, а да ће друге бити недовољно функционалне и зато касније одбачене од стране самог система. Има и таквих за које се одмах може претпоставити да би у систему могле покренути низ других промена, што би у мањој или већој мери могло нарушити његову структуру и функционисање. За неке иновације већ можемо наћи у говору потврде да делују у поменутом правцу. Када констатујемо да ће неке од њих временом бити одбачене од стране самог прозодијског система, дакле, унутрашњим језичким процесом а не напорима стручњака, онда се приближавамо заблуди која није ретка ни код стручњака, а то је да ће се све решити само по себи и без уплитања са стране. Језик у целини има ово драгоцено својство, он доиста допушта у многим својим подсистемима појаву нових или паралелних облика, одмерава њихову сврсисходност и уклапање у постојеће структуре, процењује функционалност и на крају одлучује да ли да такве елементе задржи или да их одбаци. Али, за то му је потребно много времена, повољни услови за миран језички развој и одсуство реметилачких чинилаца. Како се види, доста од побројаног зависи од спољашњих чинилаца, а не од самог језика и његових унутрашњих законитости. У сваком времену које не обезбеђује ове услове, језик неће моћи да у свему функционише лако и на уобичајени начин, па неће моћи увек да савлада ни неповољне утицаје на које буде наилазио. У времену које је бурно, нестабилно или на који други начин неповољно за миран језички развој, настајање и путеви језичких промена мораће да се прилагоде спољашњим приликама и тада ће додатна друштвена брига за опстанак и развој језика бити и неопходна и корисна.

За разлику од других језичких подсистема, фонетско-прозодијска структура постоји само у живом говору, а то је и иначе сфера која се одликује посебном 
динамиком, брзом реализацијом, тренутном реакцијом говорника, специфичним дискурсним обликовањем. Ову базичну фонетско-прозодијску структуру неједнако дотичу спољашњи утицаји: њен уже фонетски инвентар доста је чврст, основне карактеристике гласовне базе нису лако подложне променама. Можемо узети као пример вокалску боју, која се неће моћи променити а да то одмах не изазове последице по идентитет и препознатљивост самих вокала. За разлику од овога, у њен прозодијски део лакше ће улазити различите иновације, аналогије и новостворене акценатске варијанте, дијалекатски и индивидуални утицаји. Томе ће погодовати разложивост прозодијских јединица на елементе који се могу мењати појединачно - тон, трајање, место реализације - али се у променама ови елементи могу и удруживати у најразличитијим комбинацијама. Наш акценатски систем је, како је добро познато, сложен и по великом броју елемената (четири акцента са опозицијама по тону и квантитету, плус неакцентоване дужине), а сложен је и по њиховој дистрибуцији у оквиру врло бројних и врло различитих парадигми. Ово погодује тенденцији упрошћавања система, не у свим говорима и не једнако у онима где је процес већ у току, али је ова латентна могућност унутрашњег престројавања додатна олакшица продирању различитих спољашњих утицаја.

Овакве процесе смо приметили и пре десет или петнаест година, али они тада нису били једнако чести као сада. Пре свега, били су активни само у појединим друштвеним срединама, или код говорника одређеног дијалекатског порекла, а неки углавном код млађе урбане популације. Поједини облици су тада у неким срединама били сасвим ретки или потпуно одсутни. Зато је интересантно анализирати садашње стање у развоју ових тенденција, уочити учестаност и начине њиховог 
појављивања, те проценити јесу ли то раније биле случајне, привремене појаве са карактером језичког експеримента и говорне моде, или озбиљне иновације које су се учврстиле у језичком систему. Сви примери које овде износимо забележени су у периоду од октобра 2018. до септембра 2019. године.

Велики број посматраних промена настаје губљењем једног прозодијског елемента или променом једне акценатске компоненте, чиме се аутоматски мења акценатски лик речи у којој се ово догађа. Процес се обично на овоме не завршава. Нови акценатски лик речи најчешће се поклапа са неким већ постојећим обликом у систему, али је тај облик из друге акценатске парадигме, у оквиру које постоји и друга дистрибуција акценатских елемената. Даље делује аналошки процес - кад су се већ изједначила прва два облика речи, почињу да се изједначавају и остали. То се лепо може пратити на примерима једне широко распрострањене именичке парадигме коју карактерише, свим акцентолозима познати модел (познат и најмлађима од њих, мислим овде на студенте српског језика са београдског Филолошког факултета). То је модел са врло карактеристичним мелодијско-ритмичким обрасцем, који чине краткоузлазни акценат и неакцентована дужина у првом наредном слогу. Ово је један од базичних акценатских модела српског језика, настао у периоду новоштокавског метатонијског преношења акцената и имају га хиљаде наших речи. Овакви су примери:

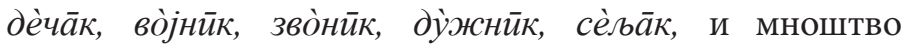
других. Обавезни елеменат модела је неакцентована дужина непосредно после акцента, али модел није везан за први слог, важно је само да дужина долази непосредно после акцента. Модел се показао веома продуктивним, па је примењиван вековима у огромном 
броју акценатских адаптација страних речи, свуда где су постојали одговарајући прозодијски услови. Тако имамо:

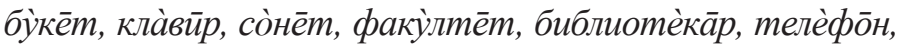
инстѝтӯm, капацйте̄т, пѝлотm, офѝийр, генѐра̄л, жѝле̄m, о̀кте̄m, секрѐта̄p, Па̀рӣз, Ло̀ндо̄н, Бѐрлйн и многе друге примере. Парадигма са оваквим ликовима номинатива, веома је карактеристична: у зависним падежима, на месту оне дужине из номинатива, обавезно се појављује дугоузлазни акценат: деча́ка, буке́та, факулте́та, библиотека́ра, телефо́на, Пари́за. Ако се код говорника изгуби неакцентована дужина, неће бити ни дугоузлазног акцента на њеном месту. Добићемо ликове који веома необично звуче онима који нису дужину изгубили и који чувају парадигму у пређашњем, исправном облику: песма из новог ӓлбума (место албу́ма) и примере који уз то имају и додатно, врло типично мењање места акцента тунел на кӧридору 10 (м. на коридо́ру) посао у Тр̈стенику (м. у Трстени́ку) .

Да је у овом мелодијско-ритмичком моделу природа тонске компоненте важна колико и неакцентована дужина, показују примери са задржаном дужином, али промењеном тонском компонентом. Уместо да се у парадигми сачува преношење акцента на слог са дотадашњом дужином, ми имамо задржавање места акцента, а тиме и напуштање дотадашње парадигме и прелазак у нову. Овакви су примери типа: дёч $\bar{a} к, ~ д е ̈ ч \overline{a \kappa ~}$ који тако прелази у парадигму типа пёснӣк, пёснйка, а затим овакви примери губе и дужину и тако настају облици дёчак, дёчака. Овако је и код бројних других примера, где говорници или немају у говору неакцентовану дужину, или не разликују по тону два кратка акцента. Ово је чест случај у дијалектима који имају такозвано метатаксичко преношење уместо метатонијског. И док њихов изговор веома изненађује говорнике (пре свега оне западно од Дрине) који не само да сами немају оваквих облика, 
него их никада у својим срединама нису ни чули, дотле је у Србији, чак и код оних који сами овако не говоре, последњих година расла толеранција према појединима од њих. Они су постајали једна врста говорне моде. Од свих оваквих промењених парадигми најчешће се, у време вишегодишњих великих саобраћајних радова у Србији, чула парадигма кӧридор, кӧридора (м. корѝдорр, коридо́ра), а у време изградње новог моста на Дунаву, појавила се, и постала веома честа, парадигма Пӱпин, Пӱпина (м. Пу̀nйн, Пупи́на). У исто време кад и примере типа мост носи име Михајла Пуипина, и ради у Пӱпину (мисли се на научни институт), забележили смо и примере аутори и рёжнсери (м. режсисе́ри), мётеори (м. метео́ри), обавезан вам је и мӓјоран (м. мајоेра̄н). Једини пример овог типа, који смо забележили са променом тона и очувањем дужине, али који није изазвао нарушавање парадигме био је овај кад је играо у Мӧрна̄ру и, код истог говорника, да није отишао из Морна́ра, дакле са исправним облицима зависних падежа. Могуће је да овде и немамо прави краткосилазни акценат у номинативу, већ тип узлазног кратког, какав се често чује у региону Ужица и у још неким срединама, а који има појачан интензитет и врло кратко трајање, што у перцепцији ствара утисак краткосилазног акцента. Последњи примери (рёжисери, мӓјоран, мётеори) имали су и промену места акцента, као што је то било и у примеру на кӧридору 10. Овакве промене, како видимо, нарушавају не само једну акценатску парадигму, већ уносе пометњу у базичне односе који су успостављени у акценатском систему српског језика и зато их треба искључивати из употребе и свуда где има прилике објашњавати разлоге за то.

Ово нас уводи у посебан проблем мењања места акцента, његовим карактеристичним пребацивањем на први слог. Видећемо да је ово посебна промена, која се одвија и ван везе са метатонијским процесом, ту може- 
мо рећи да се проблем непознавања и избегавања метатонијског процеса само повезао са тенденцијом оваквог преношења, скоро да бисмо могли рећи преношења свега и свачега на први слог. Овакав процес смо констатовали и раније, његове реализације су већини резале ухо и биле су скоро увек везане за јасно дијалекатско порекло говорника. Оне и даље имају дијалекатски, јужни и југоисточни извор, али уместо пређашњег неодобравања, сада наилазе на бољи, толерантнији пријем, а део њих и на усвајање од стране оних који са оваквим пореклом немају никакве везе. Посебно је важно што је број овако измењених акценатских облика у међувремену вишеструко повећан. То највероватније није само због простог повећања дијалекатске популације која се преселила на север, већ је добрим делом условљено и прихватањем оваквих модела од стране говорника код којих се раније они нису могли чути. Занимљиво је да смо за један део оваквих говорника, који раније нису овако говорили, али сада говоре, могли у разговору открити да су старином ипак из јужних подручја, да су они у породици друга или чешће трећа генерација рођена у Београду, што даје основа за претпоставку да су одрастали и развијали своје језичко осећење добрим делом под утицајем старијих генерација, које су добро чувале старе језичке моделе, донесене са југа. Код другог дела који није велики, али је такође занимљив, у питању је најмлађа од испитиваних популација, реч је о говорној моди. Њима се просто свиђа да уносе новине, немају сопствени критеријум или знање о акценатским појавама, што је и природно јер осим говорном праксом, никако нису везани за језичку проблематику, али ова појава предуго траје да би се могла све време називати говорном модом. Како је у протеклој деценији постала изузетно фреквентна, а на акценатском плану 
веома мења устаљене односе, на њу би требало посебно обратити пажњу.

Понекад су саме акценатске парадигме осетљиве и да тако кажемо рањиве, као што је то у случају оних парадигми са малим бројем примера који су се одржале до нашег времена, а које су окружене сроднима са доста заједничких особина. Погледајмо као пример облике свѐдок, сведо̀ка - овде имамо исправно преношење краткоузлазног акцента у зависним падежима једнине и у свим падежним облицима множине. Паралелно са овом, постоје и формално сличне акценатске парадигме, рецимо она са истим овим краткоузлазним акцентом у номинативу и зависним падежима једнине. То је тип ѝзвор, ѝзвора, али овде акценат не мења место у зависним падежима. Поред тога имамо и, опет формално сличну, парадигму са акцентом који такође не мења место и такође је сличне силабичке структуре, али му је тон силазан: пёка̄p, пёка̄pa. Чујемо овде и

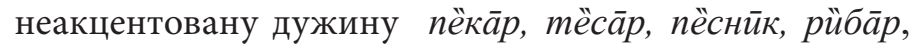
што одмах подсећа на онај фреквентни и, видели смо, веома типични за српски језик тип са истом оваквом

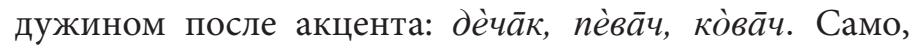
постоји међу њима битна разлика, која унапред раздваја њихове парадигме: први тип има силазни тон, а други узлазни : облик пёснйк наспрам облика дѐчйк. Други ће имати као обавезан облик у генитиву деча́ка, а не дѐчака, а први има облик пёснйка, а не песни́ка. Неке од ових парадигми окупљају многобројне примере, неке напротив, врло мали број примера. Да се и ове парадигме са малим бројем примера добро осећају у систему, показује и чињеница да се у њима појављују и нове речи (појам нов у језику је у временском смислу релативан али јасан) које се добро уклапају у модел и добро функционишу: мо̀тел, мотѐла, ба̀рок, баро̀ка, хо̀тел, хотѐла. Ако се у њима наставе неадекватне 
иновације које руше њихов парадигматски лик, свеједно да ли су те иновације дијалекатског или помодног карактера, очигледно је да то ремети прозодијске односе у систему и према њима зато не треба спуштати праг толеранције, напротив, треба имати енергије да се на едукативним платформама и свим погодним местима шири знање о исправном прозодијском обликовању и знање о разлозима зашто нешто није добро и треба га мењати. Дакле, не „зато што норма тако каже” него зато што она тиме чува и негује наш говор. Навешћемо неколико примера различитих преношења акцента на први слог, сви су забележени у последњих неколико месеци, а ниједан од наведених није био забележен само један пут. Верујемо да ће већина читалаца некима од њих бити изненађена: три ӓртикла (м. артѝкла), рӥкавац,, рӱкавца, пӧтомство, ёликсир, ёликсира, у ӧколини, није читао ӱпутства, уз помоћ мёцене, рудна бӧгатства, гёолози, сӧка̄к, сӧка̄ци, дйјалог, хйлига̄н итд.

Поставља се питање: зашто би говорницима из дијалеката који имају слободно место акцента, који дакле природно и свакодневно изговарају акценте на различитим местима у речи, било тешко да тако чине и у парадигмама стандардног језика? А јесте им тешко и они у већини случајева бирају први слог као најзгодније место акцента. Највероватнији разлози могу бити у несигурности коју мора осећати говорник из сасвим различитог прозодијског система, када се нађе пред обиљем акценатских облика и компликованих парадигми, које у много чему личе, али се опет и разликују, некад у само једном падежном облику, некад у многима, и за које уопште није сигурно да ће усвајањем акцента основног облика бити погођен и акценат осталих у парадигми. Доста брзо ови говорници постају свесни неприхватљивости акцента на ултими у стандардном језику и потребе преношења акцената даље од краја 
речи. Овоме треба додати да у свом дијалекатском језичком осећању они већ имају чврст осећај за преношење акцента на први слог, рецимо приликом префиксације глагола, па ће овај интерферентни механизам само подржати избор првог места као сигурног и погодног за већину случајева. Отуда сви они наведени облици, и заједно са њима, облици типа: морамо зӓузети став, да би та вода ӧтекла, били на пӓрастосу, турнир ће зӓпочети, зӓдржаће се, ӧсветлили су улииу и слични. Исте примере чујемо и код говорника који немају овакво дијалекатско порекло и разлози за то су други, углавном аналошки. Пре аналогије имамо два чисто акценатска разлога, јасног фонетског типа, један је то што многи не разликују у довољној мери тонску компоненту кратких акцената (неки ће се чак тиме и похвалити), а други је изведен из првог: ако немамо јасан осећај за различитост тона двају кратких акцената, немамо ни довољно јак осећај за потребу метатонијског преношења краткосилазног акцента и његово претварање у краткоузлазни акценат. А онда се на такву подлогу лако надовежу различите аналогије. Отуда примери нао што су: пӧвећати, зӓдржати, они нас тёстирају, морамо йстаћи, иако су је прӧвели заједно, после нам је то прёвела, пӧхарали су куће, йстакла је она, зӓузети простор и слични.

Још једна акценатска измена код дела глаголских облика, некад сасвим ретка ван дијалекатске сфере употребе, последњих година се веома раширила и постала данас више него приметна у београдском говору, чак и код говорника чије породице нису дијалекатског порекла. Прве примере смо бележили код београдских говорника још пре више од десет година, али су наша тадашња истраживања увек откривала непосредно дијалекатско порекло самог говорника код кога смо тај 
изговор чули, или дијалекатско порекло старијих генерација његове породице. Реч је о моделу који у стандардном језику има краткоузлазни акценат (добијен метатонијом још крајем средњег века), а код говорника које овде помињемо, он је данас замењен дугоузлазним акцентом на следећем слогу речи: напра́вила је, забора́вили су, поста́вићу, уместо исправног на̀правила је, забо̀равили су, по̀ставићу. Ово у ствари значи да је говорник невешт у метатонијском преношењу акцената, а свестан је да његови силазни акценти у овим примерима другима звуче сасвим дијалекатски (напрӓвила је, заборӓвили су, постӓвићу) и зато жели да их на неки начин измени. Он прибегава маневру при коме не мора премештати акценат, довољно му је да га учини дугим и узлазним. Питање је како то да он прибегава узлазним акцентима, које иначе говори ових дијалеката немају. Треба се сетити чињенице да јужни и југоисточни дијалекти имају у својој интонацији компоненту коју у акцентуацији немају. Они, наиме, користе узлазни тон као начин интонационог обликовања говора, пре свега као тонско обележје логичких акцената у реченици. Изговорно, фонетски, одвија се исти процес којим се у стандардном језику ствара узлазни акценат у речи. Зато овакав поступак у трансформацији акцената не ствара говорнику артикулационе тешкоће. Добијени облици имају одређени квалитет новог, необичног и свежег, врло брзо су постали примећени и почели да се имитирају и шире. Занимљиво је да код оних који су овај модел створили не срећемо облике инфинитива (напра́вити, поста́вити, забора́вити), јер њихови дијалекти облике инфинитива немају, а да код оних који су модел копирали (говорници са четвороакценатског подручја) једнако често срећемо и инфинитиве и друге облике, највише радне глаголске придеве (обич- 
но у склопу перфекта): неће он прихва́тити, лавина се обру́шила, оста́вивши их код родитеља, заме́риће ти ито си зака́снила, не може она претпоста́вити, све ће се то ускоро забора́вити.

Поменућемо још један глаголски модел настао аналогијом, који преноси акценат осталих облика презента на облик 3. лица множине, у коме је у стандардном језику и већини говора који су му у основи, акценат ду-

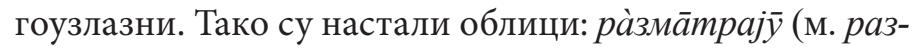

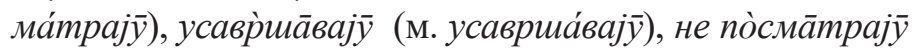

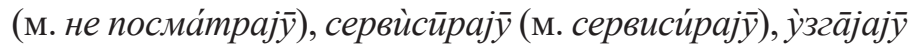
(м. узга́jajȳ). Овакве облике смо раније могли чути, као дијалекатску и регионалну одлику, само у Црној Гори, а сада имамо доста забележених облика и у Србији.

Код личних и посебно код географских имена имамо бројне појаве нарушавања постојећих парадигми. Ова појава је сада не само чешћа него раније, него у неким срединама, чак и медијским, преовлађују облици који ремете акценатске односе у систему. Навешћемо неколико облика: Ёл Пасо у Мексику, (место Ел Па̀со), кишне шуме у Ӓмазону (м. у Амазо́ну), за метро нам помажу стручњаии из Шӓнгаја (м. из Шанга́ја), био је амбасадор у Вӓтикану (м. у Ватика́ну), стигао из Йзраела, (м. из Изра̀ела), боравиће у Ӧсаки (м. у Оса̀ки). Раније је забележен велики број оваквих примера (Пӓ кистан, Дӓгестан, Хӧландија, Пйринејско полуострво, Ӓпенинско полуострво и др.), а сада је тај број још већи и, што би морало посебно да забрињава, чест је у медијској сфери, мислимо пре свега на телевизију, где је учестаност погрешних облика изузетно велика и они већ надмашују оне исправне. Посебно се ово односи на следећа три примера: Вӓтикан, Вӓтикана, Йзраел, Йзраела и Шӓнгај, Шӓнгаја, изговарана уместо исправних Ватѝка̄н, Ватика́на, Изра̀ел, Изра̀ела и 
Ша̀нга̄j, Шанга́ja. И док је пре десет или петнаест година скоро сваки говорник почињао да се колеба када му се постави питање да ли би онај други (исправни) облик некада употребио, сада се говорници не колебају и своје погрешно акцентоване облике сматрају добрима, а не мали број додаје да за друге никада није ни чуо.

Код женских имена типа Дијана, Сузана, Татјана парадигма са краткоузлазним акцентом на другом слогу повлачи се у корист парадигме са овим акцентом на првом слогу. Ова имена су раније гласила Дија̀на, Суза̀на, Tатја̀на, а онда су се паралелно почели појављивати дублетни облици - Дйјана, Су̀зана, Та̀тјана. Први од њих је најдуже очувао ранији прозодијски лик, а у последње три године облик Дија̀на је остао везан за име британске принцезе Дијане, док се паралелено са њим, у општој употреби чује скоро свуда облик Дијјана. Име Сузана је могло имати као подршку за промену два извора. С једне стране, ово име је, у гласовном облику као Зузана, распрострањено код Словака, бројних у Војводини и у њиховом говору има акценат на првом слогу. С друге стране, међу српским именима је одраније постојао акценатски модел сродних женских имена са краткоузлазним акцентом на првом слогу: Зоेрана, Смѝьана, Јо̀вана, Љѝљана. Име Татјана се аналошки придружило групи имена са акцентом на првом слогу, док је у ранијем периоду више деценија било у употреби само са акцентом на другом слогу (Татја̀на) .

Код презимена ћемо поменути само једну чињеницу: у Србији је практично изашла из употребе парадигма са основним обликом Јерѐмйћ или Паша̀лӣћ, Пантѐлйћ - свуда се чује само Јѐремић, Па̀малић, Па̀нтелић, чему основу ствара не језички него социолошки и психолошлки феномен. Наиме, акценатске облике какви су Јерѐмӣћ, Пама̀лйћ или Пантѐлӣћ овдашњи 
говорници везују за западне говоре, пре свега босанске, а то је по њиховој процени мање престижно и како су неки формулисали, „провинцијално”, па се новим акценатским ликом настоје оградити и показати да нису досељеници него „овдашњи”.

Поменућемо и један факт везан за методологију истраживања. По завршетку свих анкета и других поступака у истраживању, обично се укаже прилика за спонтани разговор са испитаницима, што може бити веома корисно за боље разумевање и касније тумачење њихових одговора, а успут им се постављају и нека питања која откривају квалитет њиховог језичког осећања, што је такође од значаја за процену попуњених упитника. Овог пута поновљена су им питања из некадашњег истраживања, са циљем да се упореди језичко осећање садашњих и некадашњих испитаника. Дати су им задаци у којима су показали како разумеју парове речи где је акценатски елеменат семантичко-диференцијални знак. Увек су се у оваквим ситуацијама испитаници добро сналазили и на основу језичког осећања давали исправне одговоре. Сада, међутим, велики број овдашњих средњошколаца и основаца уопште није видео семантичку разлику међу облицима типа: ӧпа̄сан и

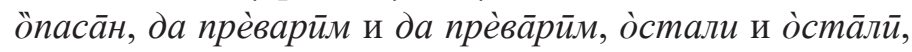
запо̀четти и зӓпоче̄тū итд. Примери су им изговарани јасно и у умереном темпу, исто као и у некадашњем испитивању, где су давани исти облици и добијени тачни одговори. У последњем наведеном примеру (запо̀четти и зӓпоче̄mū) неки су изразили мишљење да је облик запо̀че̄ти неправилан и да инфинитив треба да гласи зӓпочети. Од свих нетачних одговора овај најмање изненађује, будући да се одавно примећује повећање броја говорника из јужних и источних дијалеката, који немају осећај за новоштокавску метатонију и код којих 
су уобичајени облици као што су: пӧмоћи, ӧсванути, дӧ таћи и слични, уместо исправних, метатонијских облика помо̀ћи, осва̀нути, дота̀ћи. Како многи говорници у Београду усвајају овакве облике као говорну моду, додаћемо да се они, имамо у виду студенте српског језика из четвороакценатских подручја, врло лако враћају на исправне облике, чим се на часовима упознају са метатонијским процесима у акцентуацији. Њихово језичко осећање за метатонију је живо и реакције су доста брзе и успешне.

Једна од врло раширених заблуда везаних за вредновање прозодијских елемената и обавезност њиховог чувања у систему јесте она према којој се неакцентоване дужине не морају чувати једнако као сами акценти. Ово би значило да се различитости у акценатским парадигмама, уколико су засноване на постакценатским дужинама, не третирају једнако као оне засноване на самим акцентима. Говорници, па међу њима и многи из редова стручне јавности, обично су упознати са елементима, а ту спадају и неакцентоване дужине, који у прозодијском систему српског језика могу функционисати као семантичко-диференцијални знаци. На томе се обично и завршава њихово познавање улоге неакцентованих дужина, па ове дужине, уколико у некој речи немају улогу семантичко-диференцијалног знака, многи сматрају сувишнима, и повремено се чују предлози да се оне у таквим случајевима сматрају необавезнима, те да у систему добују статус факултативних елемената. Анализа, међутим, показује да су за функционисање укупног језичког система и процесе препознавања слухом језичких сегмената ритмички модели речи изузетно значајни. Ритмичка структура речи је за српски језик карактеристична колико и њихов гласовни састав, а за препознавање говора и разумевање 
казаног је важна ништа мање од исправног морфолошког облика. Великим делом се ритмички модели заснивају на контрастима који се успостављају међу прозодијским елементима и ту је улога трајања (акцентованих и неакцентованих) слогова изузетно велика. О овоме, осим фонетичара, мало ко размишља, па се због непознавања механизама стварања и препознавања говорних сегмената и појављују заблуде о необавезности и чак сувишности неакцентованих дужина.

Неке од иновационих тенденција, како видимо, удаљавају говорни израз од норме. Супстандардног су карактера. Њиховом брзом ширењу, поред унутарњих лингвистичких чинилаца, погодује и атмосфера пасивног односа према говорној култури и недовољна брига за прецизирање и неговање ортоепске норме. Време је бурно, језичка мода је као и свака мода омиљена, све се одвија брзо, о језику и тако мало мисли ко не мора, а дају свој допринос урбана брзина и лакоћа мењања свега око нас. Из свега казаног, као најбитније треба издвојити стварање критеријума за процену иновација, а један од њих нам сугерише да све промене које за собом вуку последице по целу парадигму, а онда и могуће аналошко деловање на друге парадигме, треба одбацивати или их оставити на супстандардном нивоу.

\section{ЛИТЕРАТУРА}

Белић, А., Laccent de la phrase et l'accent du mot, TCLP IV, 1931, 183-188

Белић, А., Језик и музика, Наш језик, књ.III, св.6, 1934, 161-166 Ивић, П., Број прозодијских могућности у речи као карактеристика фонолошких система словенских језика, ЈФ XXV, 75-113

Јакобсон, Р., Шест предаваюа о звуку и значењу, Нови Сад, 1986. 
Јокановић-Михајлов, Ј., Акценат и интонација говора на радију и телевизији, Друштво за српски језик и књижевност Србије, Београд, 2006.

Јокановић-Михајлов, Ј., Прозодија и говорна култура, Друштво за српски језик и књижевност Србије, Београд 2012.

Јокановић-Михајлов, Јелица, Акиенатски систем српског језика и наш данашни говор, Братство, XXI, Друштво “Свети Сава", Београд 2017, 39-52.

Јокановић-Михајлов, Јелица, Фонетика, фонологија и прозодија српског језика - актуелно стане и развојне перспективе, Јужнословенски филолог књ. LXXIII, св. 3-4 , Београд 2017, 207-228.

Николић, Б., Основне дијалекатске акценатске појаве у млађим новоштокавским говорима, ЈФ XXVIII, св.1-2, 1969, 189-207

Николић, Б., Акценатски системи у штокавским говорима СР Србије, ЈФ ХХІХ, св.1-2, 1972, 275-303

Петровић, Д., Две српске прозодијске норме?, II међународни научни скуп „Актуелни проблеми граматике српског језика", Суботица - Београд, 1999, стр. 227-231

Пецо, А., Вук-Даничићеви акценатски принципи и наша стандардна прозодијска норма, Наш језик, н.с. XVIII, св.1-2, 1970/71, 93-102

Peco, A., Osnovi akcentologije srpskohrvatskog jezika, Beograd, 1971. Стевановић, М., Савремени српскохрватски језик I , V изд., Научна књига, Београд, 1989.

Subotić, Lj., Sredojević, D., Bjelaković, I., Fonetika i fonologija: ortoepska $i$ ortografska norma standardnog srpskog jezika,Filozofski fakultet, Novi Sad, 2012. 
Jelica D. Jokanović-Mihajlov

\section{PROSODIC INNOVATIONS AND STABILITY OF THE ACCENTUAL PARADIGM}

\section{Summary}

Live speech is a domain where, at the accentual level, the existing phonetic and prosodic word structure meets various innovations, dialectal and individual influences. In this paper the nature of such changes is analysed, their components which change the accent or the rhythmic structure of a word are identified, and the funcional value of the new forms is estimated. Some of these changes affect not only the form in which they manifest, but also an entire paradigm, and therefore its future existence in the system. These are necessary considerations when deciding on an acceptance or a rejection of such innovations and when determining their status within the literary Serbian language.

Keyywords: accentual paradigm, innovations, orthoepy, speech culture 